\title{
Description of Fabibacter halotolerans gen. nov., sp. nov. and Roseivirga spongicola sp. nov., and reclassification of [Marinicola] seohaensis as Roseivirga seohaensis comb. nov.
}

\author{
Stanley C. K. Lau, ${ }^{1}$ Mandy M. Y. Tsoi, ${ }^{1}$ Xiancui Li, ${ }^{1}$ loulia Plakhotnikova, ${ }^{1}$ \\ Sergey Dobretsov, ${ }^{1}$ Madeline Wu, ${ }^{1}$ Po-Keung Wong, ${ }^{2}$ Joseph R. Pawlik ${ }^{3}$ \\ and Pei-Yuan Qian ${ }^{1}$ \\ ${ }^{1}$ Coastal Marine Laboratory/Department of Biology, The Hong Kong University of Science and \\ Technology, Clear Water Bay, Kowloon, Hong Kong SAR \\ ${ }^{2}$ Department of Biology, The Chinese University of Hong Kong, Shatin, New Territories, Hong \\ Kong SAR \\ ${ }^{3}$ Center for Marine Science, University of North Carolina at Wilmington, Wilmington, NC, USA
}

Correspondence

Pei-Yuan Qian

boqianpy@ust.hk
Bacterial strains UST030701-097 ${ }^{\top}$ and UST030701-084 ${ }^{\top}$ were isolated from a marine sponge in the Bahamas. Both strains were pink-pigmented, Gram-negative, strictly aerobic and chemo-organotrophic. Cells of strain UST030701-097 ${ }^{\top}$ were short, curved rods with fast-gliding motility, whereas those of strain UST030701-084 ${ }^{\top}$ were straight rods with a less rapid gliding motion. The two strains had MK-7 as the major respiratory quinone and did not produce flexirubin-type pigments. The DNA G +C contents of strains UST030701-097 ${ }^{\top}$ and UST030701-084 ${ }^{\top}$ were 42.5 and 43.7 mol\%, respectively. Phylogenetic analysis based on $16 \mathrm{~S}$ rRNA gene sequences indicated that the two strains belonged to the family 'Flexibacteraceae' of the phylum Bacteroidetes. 16S rRNA gene sequence similarity between strains UST030701-097 ${ }^{\top}$ and UST030701-084 ${ }^{\top}$ was $95.0 \%$; their closest relative was [Marinicola] seohaensis, with $93.3 \%$ and $96.0 \%$ sequence similarity, respectively. Phylogenetic tree topology indicated that the two strains belonged to the same lineage, but were on separate branches. Whilst strain UST030701-084 ${ }^{\top}$ and [Marinicola] seohaensis were found on one branch, strain UST030701-097 ${ }^{\top}$ was in another branch that had no species with validly published names. Based on the polyphasic taxonomic data obtained in the present study, we propose that strain UST030701-097 ${ }^{\top}$ represents a novel genus and that strain UST030701-084 ${ }^{\top}$ represents a novel species in the phylum Bacteroidetes. The genus Fabibacter gen. nov. is proposed, with strain UST030701-097 ${ }^{\top}\left(=\right.$ NRRL B- $41220^{\top}=$ JCM $\left.13334^{\top}\right)$ as the type strain of the type species, Fabibacter halotolerans sp. nov. Strain UST030701-084 ${ }^{\top}\left(=\right.$ NRRL B- $41219^{\top}=$ JCM $\left.13337^{\top}\right)$ is proposed as the type strain of Roseivirga spongicola sp. nov. In an earlier study, it was suggested that the genus Marinicola is a later heterotypic synonym of the genus Roseivirga. However, a formal proposal to reclassify [Marinicola] seohaensis, the only member of the genus Marinicola, has not yet been made. The results of phylogenetic analyses in this study support the reclassification of [Marinicola] seohaensis as Roseivirga seohaensis comb. nov.
Many marine sponges harbour large quantities of live bacteria. Bacterial numbers in sponges have been estimated to be as high as $10^{8}$ cells ( $\mathrm{g}$ tissue) ${ }^{-1}$ or up to $57 \%$ of tissue volume (Hentschel et al., 2003). These bacteria can be maternal in origin or captured from sea water as the sponges filter feed (Imhoff \& Stohr, 2003). The bacteria associated with sponges are believed to play essential roles in their survival and fitness. For example, the bioactive metabolites

The GenBank/EMBL/DDBJ accession numbers for the 16S rRNA gene sequences of strains UST030701-097 ${ }^{\top}$ and UST030701-084 $^{\top}$ are DQ080995 and DQ080996, respectively.

Tables detailing the results of API 20E, 20NE and 50CH tests and MicroLog 3 tests for strains UST030701-097 ${ }^{\top}$ and USTO30701-084 $^{\top}$ and scanning electron micrographs of cells of the two strains are available as supplementary material in IJSEM Online. 
of bacteria may defend sponges against epibiosis (Chelossi et al., 2004) and the extracellular enzymes of the bacteria may mobilize food resources that are otherwise indigestible by sponges (Wilkinson et al., 1999). During the course of studying bacterial communities associated with the marine sponge Tedania ignis in the Bahamas, bacterial strains UST030701-097 ${ }^{\mathrm{T}}$ and UST030701-084 ${ }^{\mathrm{T}}$ were isolated. The strains appeared as pink-pigmented, circular, convex colonies (2-4 $\mathrm{mm}$ in diameter) with a smooth surface and an entire margin after $48 \mathrm{~h}$ of cultivation at $30^{\circ} \mathrm{C}$ on an agar medium composed of 5 g peptone $\mathrm{l}^{-1}, 3 \mathrm{~g}$ yeast extract $\mathrm{l}^{-1}$ (both obtained from Oxoid) and $0 \cdot 22 \mu \mathrm{m}$-filtered sea water. This agar medium is hereafter referred to as marine agar. Unless otherwise specified, all the characteristics described hereafter are based on cultures grown on marine agar at $30{ }^{\circ} \mathrm{C}$ for $48 \mathrm{~h}$. Based on the polyphasic taxonomic data obtained in the present study, we propose that strain UST030701-097 ${ }^{\mathrm{T}}$ represents a novel genus and that strain UST030701-084 ${ }^{\mathrm{T}}$ represents a novel species within the family 'Flexibacteraceae' of the phylum Bacteroidetes.

The nearly complete $16 \mathrm{~S}$ rRNA gene sequences of strains UST030701-097 ${ }^{\mathrm{T}}$ (1412 bp) and UST030701-084 ${ }^{\mathrm{T}}$ (1387 bp) were obtained bidirectionally with replications $(n=3)$ as described elsewhere (Lau et al., 2004). Phylogenetic analysis based on nearly complete $16 \mathrm{~S}$ rRNA gene sequences indicated that the two strains shared $95.0 \%$ sequence similarity and were members of the family 'Flexibacteraceae' in the phylum Bacteroidetes. Strain UST030701-084 ${ }^{\mathrm{T}}$ was most closely related to members of the genera Marinicola (Yoon et al., 2005) and Roseivirga (Nedashkovskaya et al., $2005 a$, b), with $95 \cdot 8-96 \cdot 0 \%$ sequence similarity. Strain UST030701-097 ${ }^{\mathrm{T}}$ was most closely related to two uncharacterized bacteria (strains PM13 and DG1129), with 94.8$96.5 \%$ sequence similarity, and to the members of the genera Marinicola and Roseivirga, with $93 \cdot 1-93 \cdot 3 \%$ sequence similarity. A neighbour-joining phylogenetic tree constructed using the ARB software package (Ludwig et al., 2004) indicated that strains UST030701-097 ${ }^{\mathrm{T}}$ and UST030701-084 ${ }^{\mathrm{T}}$, the uncharacterized strains PM13 and DG1129 and members of the genera Marinicola and Roseivirga belonged to the same lineage. Within this lineage, strain UST030701-097 ${ }^{\mathrm{T}}$ and the two uncharacterized bacteria constituted one branch, whereas strain UST030701-084 ${ }^{\mathrm{T}}$ and the members of the genera Marinicola and Roseivirga constituted another (Fig. 1). This tree topology is supported by high bootstrap values within the lineage ( $>84 \%, 500$ replicates) and by its recurrence in maximum-parsimony and maximum-likelihood trees as determined using the ARB software package (Fig. 1).

Nedashkovskaya et al. (2005b) proposed that the genus Marinicola is a later heterotypic synonym of the genus Roseivirga due to many common genomic, chemotaxonomic and phenotypic features seen between members of

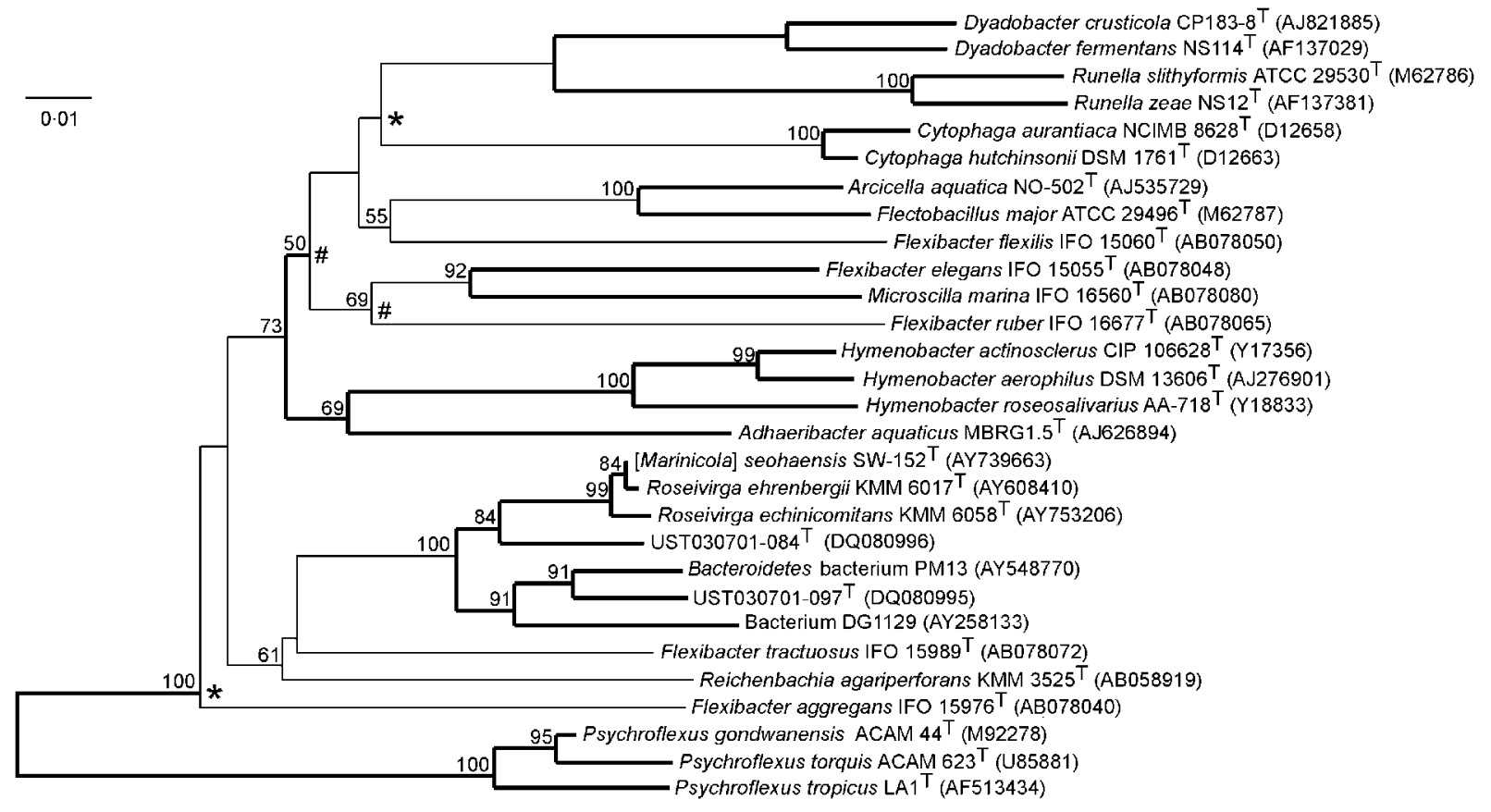

Fig. 1. Neighbour-joining dendrogram showing the estimated phylogenetic relationships between strains UST030701-097 and UST030701-084 ${ }^{\top}$ and related species on the basis of $16 \mathrm{~S}$ rRNA gene sequences. Strains belonging to the genus Psychroflexus serve as outgroups. Nodes also found in the maximum-likelihood tree are marked with \#. Nodes also found in the maximum-parsimony tree are shown by *. Lines in bold type indicate branches found in both the maximum-likelihood and maximum-parsimony trees. Bootstrap values of $\geqslant 50 \%$ (500 replicates) are indicated at the nodes. GenBank accession numbers are shown in parentheses. Bar, 1 nucleotide substitution per 100 nucleotides. 
the two genera. However, a formal proposal to reclassify [Marinicola] seohaensis, the only member of the genus Marinicola, has not yet been made. The results of the phylogenetic analysis in the study support the reclassification of [Marinicola] seohaensis to the genus Roseivirga. We thus propose that [Marinicola] seohaensis be renamed as Roseivirga seohaensis comb. nov.

The DNA G + C contents of strains UST030701-097 ${ }^{\mathrm{T}}$ and UST030701- $084^{\mathrm{T}}$ were $42 \cdot 5 \pm 0 \cdot 3 \mathrm{~mol} \%$ (three replicates) and $43 \cdot 7 \pm 0.6 \mathrm{~mol} \%$ (three replicates), respectively, as determined by an HPLC method according to Mesbah et al. (1989). MK-7 was the major respiratory quinone in both strains as determined using an HPLC method described by Collins (1994). Menaquinones extracted from Cellulophaga lytica (Johansen et al., 1999) and Pedobacter heparinus (Steyn et al., 1998) were used as references for MK-6 and MK-7, respectively. Fatty acid contents of strains UST030701-097 ${ }^{\mathrm{T}}$ and UST030701-084 ${ }^{\mathrm{T}}$ were determined using the Sherlock Microbial Identification System (MIDI) according to the manufacturer's protocol and are given in Table 1 . The fatty acid profile of the two strains differed mainly by the presence/absence of i14:0, i14:0 3-OH, 15:0 $3-\mathrm{OH}, 16: 03-\mathrm{OH}, \mathrm{i} 16: 1$ and $\mathrm{i} 17: 1 \omega 9 \mathrm{c}$ and by the quantity of i15:0 3-OH, a15:0, i16:0 3-OH, 17:0 2-OH, i17:0 3$\mathrm{OH}$ and summed feature 3 (SF3; comprising i15:0 2-OH

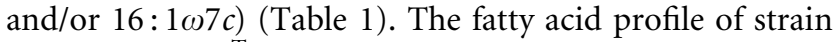
UST030701-097 ${ }^{\mathrm{T}}$ differed from those described for the members of the Marinicola and Roseivirga mainly by having larger quantities of i15:0 3-OH, i16:0 3-OH and SF3 and by the additional presence of i14:0 3-OH, 15:0 2-OH and 15:0 3-OH (Table 1). The fatty acid profile of strain UST030701-084 ${ }^{\mathrm{T}}$ could be distinguished from those of species of the genera Marinicola and Roseivirga mainly by having different quantities of i13:0, i15:1, i16:0 3-OH, $17: 02-\mathrm{OH}, \mathrm{i} 17: 03-\mathrm{OH}$ and $\mathrm{i} 17: 1 \omega 9 \mathrm{c}$ and by the additional presence of 15:0 2-OH (Table 1).

Anaerobic growth of the two novel strains was examined in the Oxoid Anaerobic System. The requirement for $\mathrm{NaCl}$ was tested in a medium containing $\left(\mathrm{l}^{-1}\right) 5 \mathrm{~g} \mathrm{MgCl}_{2}, 2 \mathrm{~g} \mathrm{MgSO}_{4}$, $0.5 \mathrm{~g} \mathrm{CaCl}_{2}, 1 \mathrm{~g} \mathrm{KCl}, 5 \mathrm{~g}$ peptone and various amounts of $\mathrm{NaCl}$, adjusted to $\mathrm{pH} 7 \cdot 5$ using $\mathrm{KOH}$ (Isnansetyo \& Kamei, 2003). Cell morphology was examined using scanning electron microscopy (7600F; JEOL) according to the procedures described in Neu et al. (2001) (see Supplementary Fig. S1 in IJSEM Online). Reaction to Gram-stain was determined using light microscopy according to Smibert \& Krieg (1994). Gliding motility was determined using phase-contrast light microscopy (Olympus) after growth on quarter-strength marine 2216 medium solidified with $1 \%$ agar according to Bowman (2000). Susceptibility to antibiotics was tested by the routine disc-diffusion plate method according to Acar (1980). Flexirubin-type pigment production and carboxymethylcellulose hydrolysis were determined according to Bernardet et al. (2002). Casein hydrolysis was determined according to Norris et al. (1985). Hydrolysis of chitin and Tweens 20, 40 and 80 was performed by using the method
Table 1. Comparison of major cellular fatty acids for strains UST030701-097 ${ }^{\top}$ and UST030701-084 ${ }^{\top}$ and recognized members of the genera Marinicola and Roseivirga

Strains/species: 1, UST030701-097 ${ }^{\mathrm{T}} ; \quad$ 2, UST030701-084 ${ }^{\mathrm{T}} ; \quad$, [Marinicola] seohaensis; 4, Roseivirga ehrenbergii; 5, Roseivirga echinicomitans. The growth conditions for strains UST030701-097 ${ }^{\mathrm{T}}$ and UST030701-084 ${ }^{\mathrm{T}}$ were marine agar (as described earlier in this study) and incubation at $30{ }^{\circ} \mathrm{C}$ for 2 days. [Marinicola] seohaensis was grown in Marine agar 2216 at $30^{\circ} \mathrm{C}$ for 3 days. The growth conditions for $R$. ehrenbergii and $R$. echinicomitans are not given. Values are percentages of total fatty acids. -, Not detected. Data for [M.] seohaensis, R. ehrenbergii and R. echinicomitans are from Yoon et al. (2005) and Nedashkovskaya et al. (2005a, b).

\begin{tabular}{|lrcccc|}
\hline Fatty acid & $\mathbf{1}$ & $\mathbf{2}$ & $\mathbf{3}$ & $\mathbf{4}$ & $\mathbf{5}$ \\
\hline i13:0 & $1 \cdot 6$ & $0 \cdot 7$ & $5 \cdot 2$ & $3 \cdot 2$ & $2 \cdot 9$ \\
i1 $4: 0$ & $4 \cdot 7$ & - & - & - & $1 \cdot 9$ \\
i14:0 3-OH & $1 \cdot 1$ & - & - & - & - \\
$15: 0$ 2-OH & $1 \cdot 9$ & $3 \cdot 2$ & - & - & - \\
$15: 03-\mathrm{OH}$ & $1 \cdot 3$ & - & - & - & - \\
i15:0 3-OH & $12 \cdot 5$ & $4 \cdot 9$ & $5 \cdot 6$ & $3 \cdot 0$ & $4 \cdot 1$ \\
a15:0 & $2 \cdot 5$ & $12 \cdot 5$ & $2 \cdot 4$ & $4 \cdot 5$ & $13 \cdot 1$ \\
i15:0 & $18 \cdot 3$ & $18 \cdot 6$ & $33 \cdot 5$ & $24 \cdot 0$ & $20 \cdot 2$ \\
a15: 1 & $0 \cdot 8$ & - & - & $1 \cdot 8$ & $2 \cdot 4$ \\
i15: & $14 \cdot 2$ & $12 \cdot 5$ & $20 \cdot 5$ & $34 \cdot 2$ & $20 \cdot 2$ \\
$16: 03-\mathrm{OH}$ & $1 \cdot 2$ & - & $1 \cdot 8$ & $1 \cdot 6$ & - \\
i16:0 & $1 \cdot 2$ & $2 \cdot 0$ & $1 \cdot 2$ & $1 \cdot 1$ & $1 \cdot 8$ \\
i16:1 & $1 \cdot 2$ & - & - & - & $2 \cdot 0$ \\
i16:0 3-OH & $12 \cdot 7$ & $1 \cdot 2$ & $7 \cdot 2$ & $4 \cdot 1$ & $4 \cdot 2$ \\
$17: 02-\mathrm{OH}$ & $1 \cdot 3$ & $10 \cdot 1$ & - & - & $2 \cdot 0$ \\
i17:0 & $0 \cdot 5$ & - & - & - & $1 \cdot 0$ \\
i17:0 3-OH & $9 \cdot 3$ & $18 \cdot 3$ & $11 \cdot 2$ & $7 \cdot 7$ & $12 \cdot 1$ \\
i17: $1 \omega 9 c$ & - & $10 \cdot 8$ & - & - & $1 \cdot 1$ \\
SF3 & $13 \cdot 7$ & $5 \cdot 5$ & $4 \cdot 8$ & $1 \cdot 7$ & $1 \cdot 0$ \\
& & & & \\
\hline
\end{tabular}

${ }^{\star}$ Summed feature 3 comprises i15:0 2-OH and/or $16: 1 \omega 7 c$.

of Baumann \& Baumann (1988). Oxidase and catalase activities and the hydrolysis of agar, DNA and starch were tested according to Smibert \& Krieg (1994). Other enzyme activities, growth on carbon sources, acid production from carbon sources, nitrate reduction and the production of $\mathrm{H}_{2} \mathrm{~S}$, indole and acetoin were tested using the API 20E, API 20NE, API 50CH, API ZYM (bioMérieux) and MicroLog 3 (Biolog) commercial systems. Cells for inoculation into the API systems were suspended in a sterile solution of a seawater mixture at $22 \%$ salinity (MacDonell et al., 1982). The phenotypic characteristics of strains UST030701-097 ${ }^{\mathrm{T}}$ and UST030701-084 ${ }^{\mathrm{T}}$ are given in the genus/species descriptions. Results obtained from the API and MicroLog 3 systems are detailed in Supplementary Tables S1-S3 in IJSEM Online.

Chemotaxonomic and phenotypic characteristics that distinguish strain UST030701-084 ${ }^{\mathrm{T}}$ from other members of the genera Marinicola and Roseivirga are given in Tables 1 and 2. Characteristics that distinguish strain UST030701-097 ${ }^{\mathrm{T}}$ 
Table 2. Characteristics that differentiate strain UST030701-084 ${ }^{\top}$ from recognized species of the genera Marinicola and Roseivirga

Strains/species: 1, UST030701-084 ${ }^{\mathrm{T}} ; 2$, [Marinicola] seohaensis; 3, Roseivirga ehrenbergii; 4, Roseivirga echinicomitans. +, Positive; (+), weakly positive; -, negative; ND, not determined. Data for [Marinicola] seohaensis, R. ehrenbergii and R. echinicomitans are from Yoon et al. (2005) and Nedashkovskaya et al. (2005a, b).

\begin{tabular}{|c|c|c|c|c|}
\hline Characteristic & 1 & 2 & 3 & 4 \\
\hline DNA G $+\mathrm{C}$ content $(\mathrm{mol} \%)$ & $43 \cdot 7$ & $40 \cdot 1$ & $40 \cdot 2$ & $41 \cdot 3$ \\
\hline $\mathrm{NaCl}$ range for growth $(\%)$ & $0-16 \cdot 0$ & $2 \cdot 0-9 \cdot 0$ & $1 \cdot 0-8 \cdot 0$ & $1 \cdot 0-8 \cdot 0$ \\
\hline Temperature range for growth $\left({ }^{\circ} \mathrm{C}\right)$ & $12 \cdot 0-44 \cdot 0$ & $4 \cdot 0-40 \cdot 0$ & $4 \cdot 0-39 \cdot 0$ & $4 \cdot 0-31 \cdot 0$ \\
\hline Pigmentation & Pink & Orange & Pink & Pink \\
\hline Flexirubin & - & + & - & - \\
\hline Gliding motility & + & + & - & - \\
\hline \multicolumn{5}{|l|}{ Hydrolysis of: } \\
\hline DNA & + & ND & + & - \\
\hline Gelatin & + & - & + & + \\
\hline Tween 20 & + & $(+)$ & + & - \\
\hline Tween 40 & + & $(+)$ & - & + \\
\hline Tween 80 & + & $(+)$ & - & - \\
\hline Reduction of nitrate & - & - & - & + \\
\hline \multicolumn{5}{|l|}{ Enzyme activities: } \\
\hline Cystine arylamidase & + & - & ND & + \\
\hline$\beta$-Galactosidase & - & - & + & + \\
\hline$\alpha$-Glucosidase & + & - & ND & + \\
\hline$\beta$-Glucosidase & + & - & ND & ND \\
\hline Lipase & + & - & ND & ND \\
\hline Trypsin & + & - & ND & + \\
\hline
\end{tabular}

from other genera in the phylum Bacteroidetes are detailed in Table 3. Most notably, strains UST030701-097 ${ }^{\mathrm{T}}$ and UST030701-084 ${ }^{\mathrm{T}}$ differ from their close relatives by being more halotolerant, but not requiring $\mathrm{NaCl}$ for growth. Moreover, strain UST030701-097 ${ }^{\mathrm{T}}$ has a distinctive curved cell shape and strain UST030701-084 ${ }^{\mathrm{T}}$ has a range of hydrolytic and enzyme activities not found in other members of the genera Marinicola and Roseivirga. Strains UST030701$097^{\mathrm{T}}$ and UST030701-084 ${ }^{\mathrm{T}}$ differ from each other by: (i) cell shape, (ii) halo- and thermotolerance levels, (iii) gelatin hydrolysis and arginine dihydrolase, $\alpha$-galactosidase, $\beta$ galactosidase and $\alpha$-mannosidase activities and (iv) susceptibility to ampicillin, penicillin, streptomycin and tetracycline. Strain UST030701-097 ${ }^{\mathrm{T}}$ is able to utilize a variety of sole carbon sources in the API and MicroLog 3 systems, while strain UST030701-084 ${ }^{\mathrm{T}}$ can only utilize aesculin ferric citrate in the API $50 \mathrm{CH}$ system and $\alpha$ ketovaleric acid in the MicroLog 3 system (see Supplementary Tables S2 and S3 in IJSEM Online). The small number of carbon sources utilized by strain UST030701-084 $4^{\mathrm{T}}$ is a feature also found in the members of the genus Roseivirga. Molecular evidence, together with chemotaxonomic and phenotypic characteristics, suggest that strain UST030701-097 ${ }^{\mathrm{T}}$ represents a novel genus and that strain UST030701-084 ${ }^{\mathrm{T}}$ represents a novel species within the phylum Bacteroidetes. The name Fabibacter halotolerans gen. nov., sp. nov., is proposed for strain
UST030701-097 ${ }^{\mathrm{T}}$. Strain UST030701-084 ${ }^{\mathrm{T}}$ is proposed as Roseivirga spongicola sp. nov.

\section{Description of Fabibacter gen. nov.}

Fabibacter [Fa.bi.bac'ter. L. fem. n. faba bean; N.L. masc. n. bacter rod; N.L. masc. n. Fabibacter bean(-like) rod].

Cells are Gram-negative, curved rods $(1.5 \mu \mathrm{m}$ long $\times$ $0.5 \mu \mathrm{m}$ wide). Strictly aerobic and chemo-organotrophic. The major respiratory quinone is MK-7. Flexirubin-type pigments are not produced. Oxidase- and catalase-positive. Phylogenetic analysis based on 16S rRNA gene sequence indicates that the genus is a member of the family 'Flexibacteraceae in the phylum Bacteroidetes.

Currently, the genus contains one species, the type species Fabibacter halotolerans.

\section{Description of Fabibacter halotolerans sp. nov.}

Fabibacter halotolerans (ha.lo.to'le.rans. Gr. masc. n. hals salt; L. part. adj. tolerans tolerating; N.L. part. adj. halotolerans salt-tolerating).

Displays the following properties in addition to those given in the genus description. Colonies on marine agar are pink, circular, $2 \cdot 0-4 \cdot 0 \mathrm{~mm}$ in diameter, convex with a smooth surface and an entire margin. No diffusible pigment. Has 
Table 3. Characteristics that differentiate strain UST030701-097 ${ }^{\top}$ from closely related genera

Taxa: 1, UST030701-097 ${ }^{\mathrm{T}}$; 2, Marinicola; 3, Roseivirga; 4, Reichenbachia; 5, Adhaeribacter, 6, Hymenobacter. +, Positive; (+), weakly positive; -, negative; ND, not determined; V, variable. Data for Roseivirga, Reichenbachia, Adhaeribacter and Hymenobacter are from Hirsch et al. (1998), Collins et al. (2000), Buczolits et al. (2002), Nedashkovskaya et al. (2003, 2005a, b), Rickard et al. (2005) and Yoon et al. (2005).

\begin{tabular}{|c|c|c|c|c|c|c|}
\hline Characteristic & 1 & 2 & 3 & 4 & 5 & 6 \\
\hline $\mathrm{NaCl}$ range for growth $(\%)$ & $0-12 \cdot 0$ & $2 \cdot 0-8 \cdot 0$ & $1 \cdot 0-8 \cdot 0$ & $1 \cdot 0-6 \cdot 0$ & $0-4 \cdot 0$ & $0-2 \cdot 0$ \\
\hline Pigmentation & Pink & Orange & Pink & Orange & Pink & Pink/red \\
\hline Flexirubin & - & + & - & + & $\mathrm{ND}$ & ND \\
\hline Cell shape & Short curved rod & Rod & Rod & Rod & Rod & Rod/coccoid \\
\hline \multicolumn{7}{|l|}{ Hydrolysis of: } \\
\hline Gelatin & - & - & + & + & $\mathrm{ND}$ & + \\
\hline Tween 80 & + & $(+)$ & - & - & ND & + \\
\hline Starch & $(+)$ & - & - & + & - & + \\
\hline Acid production from carbohydrates & + & - & - & - & - & - \\
\hline$\alpha$-Glucosidase & + & - & + & $\mathrm{ND}$ & + & $\mathrm{V}$ \\
\hline$\beta$-Glucosidase & + & - & $\mathrm{V}$ & $\mathrm{ND}$ & + & $\mathrm{V}$ \\
\hline$\alpha$-Mannosidase & + & - & $\mathrm{v}$ & ND & ND & - \\
\hline
\end{tabular}

fast-gliding motility. Growth occurs between 12 and $36{ }^{\circ} \mathrm{C}$ (optimum of $28-30{ }^{\circ} \mathrm{C}$ ) and between $\mathrm{pH} 5 \cdot 0$ and $10 \cdot 0$. Does not require sodium for growth, but can tolerate up to $12 \%$ $\mathrm{NaCl}$. In disc-diffusion tests, susceptible to ampicillin $(1 \mu \mathrm{g})$, chloramphenicol $(1 \mu \mathrm{g})$, penicillin $(1 \mu \mathrm{g})$, streptomycin $(0 \cdot 1 \mu \mathrm{g})$ and tetracycline $(5 \mu \mathrm{g})$, but not to kanamycin (tested up to $100 \mu \mathrm{g}$ ). DNA G $+\mathrm{C}$ content is $42 \cdot 5 \pm 0 \cdot 3 \mathrm{~mol} \%$. Predominant fatty acids $(>5 \%)$ are $\mathrm{i} 15: 0$, i15: 1, i15:0 3-OH, i16:0 3-OH, i17:0 3-OH and SF 3(comprising i15:0 2-OH and/or $16: 1 \omega 7 c$ ). These fatty acids represent $80.7 \%$ of the total. Produces acetoin, but not indole or $\mathrm{H}_{2} \mathrm{~S}$. Nitrate is not reduced. DNA and Tweens 20, 40 and 80 are hydrolysed, but not agar, casein, carboxymethylcellulose, chitin or gelatin. Starch is weakly hydrolysed. $N$-Acetyl- $\beta$-glucosaminidase, acid phosphatase, alkaline phosphatase, arginine dihydrolase, $\alpha$ galactosidase, $\beta$-galactosidase, $\alpha$-glucosidase, $\beta$-glucosidase, $\alpha$-chymotrypsin, cystine arylamidase, leucine arylamidase, valine arylamidase, esterase (C4), esterase lipase (C8), lipase (C14), $\alpha$-mannosidase, trypsin and naphthol-AS-BIphosphohydrolase activities are positive. No activities of $\alpha$ fucosidase, $\beta$-glucuronidase, lysine decarboxylase, ornithine decarboxylase, tryptophan deaminase or urease. Growth occurs on the following sole carbon sources in the API 20E, 20NE and 50CH systems: D-cellobiose, D-lactose, D-maltose and starch. Acid is produced from the following sole carbon sources in the API $20 \mathrm{E}$ and $50 \mathrm{CH}$ systems: amygdalin, arbutin, D-cellobiose, aesculin ferric citrate, D-galactose, Dglucose, gentiobiose, maltose, methyl $\alpha$-D-glucopyranoside, D-raffinose, salicin, sucrose, starch and D-trehalose. Utilizes the following carbon sources in the MicroLog 3 system: Lalaninamide, L-alanine, L-alanyl glycine, L-aspartic acid, D-cellobiose, dextrin, D-galacturonic acid, gentiobiose, $\alpha$-Dglucose, D-glucose 6-phosphate, L-glutamic acid, glycogen, glycyl L-aspartic acid, glycyl L-glutamic acid, $\alpha$-ketobutyric acid, $\alpha$-ketoglutaric acid, $\alpha$-ketovaleric acid, DL-lactic acid, $\alpha$-D-lactose, lactulose, maltose, D-melibiose, methyl $\beta$-Dglucoside, L-ornithine, L-proline, L-pyroglutamic acid, Draffinose, succinamic acid, sucrose, D-trehalose, turanose and L-threonine. A full list of carbon sources included in the API and MicroLog 3 systems is given in Supplementary Tables S2 and S3 in IJSEM Online.

The type strain, UST030701-097 ${ }^{\mathrm{T}}$ (=NRRL B-41220 $=$ JCM $13334^{\mathrm{T}}$ ), was isolated from the marine sponge Tedania ignis in the Bahamas.

\section{Description of Roseivirga spongicola sp. nov.}

Roseivirga spongicola [spon.gi'co.la. Late L. n. spongos -i sponge; L. masc./fem. suffix n. -cola (from incola) inhabitant; N.L. nom. n. (in apposition) spongicola inhabitant of sponges].

Cells are Gram-negative rods, $2 \cdot 0 \mu \mathrm{m}$ long $\times 0 \cdot 5 \mu \mathrm{m}$ wide, with gliding motility. Colonies on marine agar are pink, circular, $2 \cdot 0-4 \cdot 0 \mathrm{~mm}$ in diameter, convex with a smooth surface and an entire margin. No diffusible pigment. Strictly aerobic and chemo-organotrophic. Growth occurs between 12 and $44^{\circ} \mathrm{C}$ (optimum is $20-30{ }^{\circ} \mathrm{C}$ ) and between $\mathrm{pH} 5.0$ and $10 \cdot 0$. Does not require sodium for growth, but can tolerate 
up to $16 \% \mathrm{NaCl}$. The major respiratory quinone is MK-7. In disc diffusion tests, susceptible to chloramphenicol $(100 \mu \mathrm{g})$, but not to ampicillin, kanamycin, penicillin, streptomycin or tetracycline (each tested up to $100 \mu \mathrm{g}$ ). Flexirubin-type pigments are not produced. DNA G $+\mathrm{C}$ content is $43 \cdot 7 \pm$ $0.6 \mathrm{~mol} \%$. Predominant fatty acids $(>5 \%)$ are a15:0, $\mathrm{i} 15: 0, \mathrm{i} 15: 1,17: 02-\mathrm{OH}, \mathrm{i} 17: 03-\mathrm{OH}, \mathrm{i} 17: 1 \omega 9 c$ and SF 3 (comprising i15:0 2-OH and/or $16: 1 \omega 7 c$ ). These fatty acids represent $88.3 \%$ of the total. Produces acetoin, but not indole or $\mathrm{H}_{2} \mathrm{~S}$. Nitrate is not reduced. DNA, gelatin and Tweens 20, 40 and 80 are hydrolysed, but not agar, casein, carboxymethylcellulose, chitin or starch. N-Acetyl$\beta$-glucosaminidase, catalase, cystine arylamidase, leucine arylamidase, valine arylamidase, $\alpha$-chymotrypsin, oxidase, $\alpha$-glucosidase, $\beta$-glucosidase, esterase (C4), esterase lipase (C8), acid phosphatase, alkaline phosphatase, lipase (C14), naphthol-AS-BI-phosphohydrolase and trypsin activities are positive. No activities of arginine dihydrolase, $\alpha$ fucosidase, $\alpha$-galactosidase, $\beta$-galactosidase, $\beta$-glucuronidase, lysine decarboxylase, $\alpha$-mannosidase, ornithine decarboxylase, tryptophan deaminase or urease. Utilizes only aesculin ferric citrate in the API $50 \mathrm{CH}$ system and $\alpha$-ketovaleric acid in the MicroLog 3 system as sole carbon sources. No acid production from the sole carbon sources in the API 20E and $50 \mathrm{CH}$ systems. A full list of carbon sources included in the API and MicroLog 3 systems is provided in Supplementary Tables S2 and S3 in IJSEM Online.

The type strain, UST030701-084 ${ }^{\mathrm{T}}\left(=\mathrm{NRRL} \mathrm{B}-41219^{\mathrm{T}}=\right.$ JCM $13337^{\mathrm{T}}$ ), was isolated from the marine sponge Tedania ignis in the Bahamas.

\section{Description of Roseivirga seohaensis comb. nov.}

Roseivirga seohaensis (seo.ha.en'sis. N.L. fem. adj. seohaensis of Seohae, the Korean name for the Yellow Sea in Korea, from where the type strain was isolated).

Basonym: Marinicola seohaensis Yoon et al. 2005

The description is identical to that given for Marinicola seohaensis by Yoon et al. (2005). The type strain is $\mathrm{SW}-152^{\mathrm{T}}$ $\left(=\right.$ KCTC $12312^{\mathrm{T}}=$ JCM $\left.12600^{\mathrm{T}}\right)$.

\section{Acknowledgements}

We thank Mr Ken Lau for the analysis of respiratory quinones and Professor Hans G. Trüper (University of Bonn, Germany) for generous help in Latin etymology. This work was supported by grants awarded to P.Y.Q.: Research Grants Council grant no. HKUST6240/04M, University Grants Council grant no. CA04/05.Sc01 and China Ocean Mineral Resource Research and Development Association grant no. COMRRDA03/04.Sc01.

\section{References}

Acar, J. F. (1980). The disc susceptibility test. In Antibiotics in Laboratory and Medicine, pp. 24-54. Edited by V. Lorian. Baltimore: Williams \& Wilkins.
Baumann, P. \& Baumann, L. (1988). The marine Gram-negative eubacteria: genera Photobacterium, Beneckea, Alteromonas, Pseudomonas and Alcaligenes. In The Prokaryotes, vol. 1, pp. 1302-1331. Edited by M. P. Starr, H. Stolp, H. G. Trüper, A. Balows \& H. Schlegel. New York: Springer.

Bernardet, J. F., Nakagawa, Y. \& Holmes, B. (2002). Proposed minimal standards for describing new taxa of the family Flavobacteriaceae and emended description of the family. Int J Syst Evol Microbiol 52, 1049-1070.

Bowman, J. P. (2000). Description of Cellulophaga algicola sp. nov., isolated from the surfaces of Antarctic algae, and reclassification of Cytophaga uliginosa (ZoBell and Upham 1944) Reichenbach 1989 as Cellulophaga uliginosa comb. nov. Int J Syst Evol Microbiol 50, 1861-1868.

Buczolits, S., Denner, E. B. M., Vybiral, D., Wieser, M., Kämpfer, P. \& Busse, H. J. (2002). Classification of three airborne bacteria and proposal of Hymenobacter aerophilus sp. nov. Int J Syst Evol Microbiol 52, 445-456.

Chelossi, E., Milanese, M., Milano, A., Pronzato, R. \& Riccardi, G. (2004). Characterization and antimicrobial activity of epibiotic bacteria from Petrosia ficiformis (Porifera, Demospongiae). J Exp Mar Biol Ecol 309, 21-33.

Collins, M. D. (1994). Isoprenoid quinones. In Chemical Methods in Prokaryotic Systematics, pp. 265-310. Edited by M. Goodfellow \& A. G. O'Donnell. Chichester: Wiley.

Collins, M. D., Hutson, R. A., Grant, I. R. \& Patterson, M. F. (2000). Phylogenetic characterization of a novel radiation-resistant bacterium from irradiated pork: description of Hymenbacter actinosclerus sp. nov. Int J Syst Evol Microbiol 50, 731-734.

Hentschel, U., Fieseler, L., Wehrl, M., Gernert, C., Steinert, M., Hacker, J. \& Horn, M. (2003). Microbial diversity of marine sponges. In Sponges (Porifera), pp. 79-88. Edited by W. E. G. Müller. Berlin: Springer.

Hirsch, P., Ludwig, W., Hethke, C., Sittig, M., Hoffmann, B. \& Gallikowski, C. A. (1998). Hymenbacter roseosalivarius gen. nov., sp. nov. from continental Antarctica soils and sandstone: bacteria of the Cytophaga/Flavobacterium/Bacteroides line of phylogenetic descent. Syst Appl Microbiol 21, 374-383.

Imhoff, J. F. \& Stohr, R. (2003). Sponge-associated bacteria: general overview and special aspects of bacteria associated with Halichondria panicea. In Sponges (Porifera), pp. 35-57. Edited by W. E. G. Müller. Berlin: Springer.

Isnansetyo, A. \& Kamei, Y. (2003). Pseudoalteromonas phenolica sp. nov., a novel marine bacterium that produces phenolic antimethicillin-resistant Staphylococcus aureus substances. Int J Syst Evol Microbiol 53, 583-588.

Johansen, J. E., Nielsen, P. \& Sjoholm, C. (1999). Description of Cellulophaga baltica gen. nov., sp. nov. and Cellulophaga fucicola gen. nov., sp. nov. and reclassification of [Cytophaga] lytica to Cellulophaga lytica gen. nov., comb. nov. Int J Syst Bacteriol 49, 1231-1240.

Lau, S. C. K., Tsoi, M., Li, X., Plakhotnikova, I., Wu, M., Wong, P. K. \& Qian, P. Y. (2004). Loktanella hongkongensis sp. nov., a novel member of the $\alpha$-Proteobacteria originating from marine biofilms in Hong Kong waters. Int J Syst Evol Microbiol 54, 2281-2284.

Ludwig, W., Strunk, O., Westram, R. \& 29 other authors (2004). ARB: a software environment for sequence data. Nucleic Acids Res 32, 1363-1371.

MacDonell, M. T., Singleton, F. L. \& Hood, M. A. (1982). Diluent composition for use of API $20 \mathrm{E}$ characterizing marine and estuarine bacteria. Appl Environ Microbiol 44, 423-427.

Mesbah, M., Premachandran, U. \& Whitman, W. B. (1989). Precise measurement of the $\mathrm{G}+\mathrm{C}$ content of deoxyribonucleic acid by 
high-performance liquid chromatography. Int J Syst Bacteriol 39, 159-167.

Nedashkovskaya, O. I., Suzuki, M., Vysotskii, M. V. \& Mikhailov, V. V. (2003). Reichenbachia agariperforans gen. nov., sp. nov., a novel marine bacterium in the phylum Cytophaga-FlavobacteriumBacteroides. Int J Syst Evol Microbiol 53, 81-85.

Nedashkovskaya, O. I., Kim, S. B., Lee, D. H., Lysenko, A. M., Shevchenko, L. S., Frolova, G. M., Mikhailov, V. V., Lee, K. H. \& Bae, K. S. (2005a). Roseivirga ehrenbergii gen. nov., sp. nov., a novel marine bacterium of the phylum 'Bacteroidetes', isolated from the green alga Ulva fenestrata. Int J Syst Evol Microbiol 55, 231-234.

Nedashkovskaya, O. I., Kim, S. B., Lysenko, A. M., Park, M. S., Mikhailov, V. V., Bae, K. S. \& Park, H. Y. (2005b). Roseivirga echinicomitans sp. nov., a novel marine bacterium isolated from the sea urchin Stronglyocentrotus intermedius, and emended description of the genus Roseivirga. Int J Syst Evol Microbiol 55, 1797-1800.

Neu, B., Voigt, A., Mitlohner, R. \& 7 other authors (2001). Biological cells as templates for hollow microcapsules. J Microencapsul 18, 385-395.

Norris, J. R., Ribbons, D. W. \& Varma, A. K. (editors) (1985). Methods in Microbiology, vol. 18. London: Academic Press.
Rickard, A. H., Stead, A. T., O'May, G. A., Lindsay, S., Banner, M., Handley, P. S. \& Gilbert, P. (2005). Adhaeribacter aquaticus gen. nov., sp. nov., a Gram-negative isolate from a potable water biofilm. Int J Syst Evol Microbiol 55, 821-829.

Smibert, R. M. \& Krieg, N. R. (1994). Phenotypic characteristics. In Methods for General and Molecular Biology, pp. 607-654. Edited by P. Gerhardt, R. G. E. Murray, W. A. Wood, N. R. Krieg. Washington, DC: American Society for Microbiology.

Steyn, P. L., Segers, P., Vancanneyt, M., Sandra, P., Kersters, K. \& Joubert, J. J. (1998). Classification of heparinolytic bacteria into a new genus, Pedobacter, comprising four species: Pedobacter heparinus comb. nov., Pedobacter piscium comb. nov., Pedobacter africanus sp. nov. and Pedobacter saltans sp. nov. Proposal of the family Sphingobacteriaceae fam. nov. Int J Syst Bacteriol 48, 165-177.

Wilkinson, C. R., Summons, R. E. \& Evans, E. (1999). Nitrogen fixation in symbiotic marine sponges: ecological significance and difficulties in detection. Mem Queensl Mus 44, 667-673.

Yoon, J. H., Kang, S. J., Lee, C. H. \& Oh, T. K. (2005). Marinicola seohaensis gen. nov., sp. nov., isolated from sea water of the Yellow Sea, Korea. Int J Syst Evol Microbiol 55, 859-863. 